\title{
The Effect of Content-Based Approach in Student vs. Teacher-Centered Environment on Improving Speaking among Iranian Intermediate EFL Learners
}

\author{
Seyed Ehsan Afsahi ${ }^{1} \&$ Azizeh Chalak ${ }^{2}$ \\ ${ }^{1} \mathrm{PhD}$ Candidate in TEFL, Islamic Azad University, Isfahan (Khorasgan) Branch, Isfahan, Iran \\ ${ }^{2}$ Assistant Professor, Islamic Azad University, Isfahan (Khorasgan) Branch, Isfahan, Iran \\ Correspondence: Seyed Ehsan Afsahi, Islamic Azad University, Isfahan (Khorasgan) Branch, Isfahan, Iran. \\ E-mail: S.e.afsahi@gmail.com
}

Received: July 29, 2016 Accepted: October 5, 2016 Online Published: December 1, 2016

doi:10.5539/ijel.v6n7p138 URL: http://dx.doi.org/10.5539/ijel.v6n7p138

\begin{abstract}
Speaking is the most important skill of language. Speaking a language is especially difficult for foreign language learners because effective oral communication requires the ability to use the language appropriately in social interactions, and in suitable context and situation. Purpose of this study was to investigate the relationship between Iranian intermediate EFL learners who learn speaking based on content approach in student-centered environment and their learning in the traditional teacher-centered environment. To this end, there are two classes, one as the experimental and the other as the control one. The same teacher taught them both. The subjects were all homogenous regarding their age, gender, and first language. During the experiment, the experimental group, who were in the environment of content-based approach in student-centered, was received quizzes. The results indicated that a statistically significant positive relationship existed between giving the students the central role in content-based approach class and yielding in better performance of speaking ability. The results revealed the positive relationship between content-based approach in student-centered class and the improvement of EFL Iranian students' speaking ability. Preparation of such a system for teaching speaking to learners, learning English as a foreign language will facilitate the teaching and learning process for both teachers and learners.
\end{abstract}

Keywords: content-based approach, student-centered approach, teacher-centered approach

\section{Introduction}

Although most of the scholars in the field of TEFL consider student centered classes an important factor in the language development of the learner, there does not seem to be an agreement on the central role of the students in the course. The scholars believe that the students can handle a more effective role through the course only if they are paid more credit and are valued by the teacher. In such a case, those introverted individuals will be more outgoing \& extroverted. Speaking is an interactive process of constructing meaning that involves producing and receiving and processing information. The researcher assumes that one of the major drawbacks to the commonly used speaking approach do not result well in developing it.

As a matter of fact, most of the learners consider speaking as an important ability to have which is useful in different situation. The present study aims at implementing the content-based approach in a student-centered environment with Iranian intermediate EFL learners to help them to have interaction with a realistic task such as panel discussion for better improvement of the speaking skill. It will be very beneficial for EFL teachers to widen their view on the new methods of teaching and considering the roles assumed to both parts as it really deserves and yields better learning outcomes.

Possibly, recognition of the value of a student centered role in the classes or perhaps the other alternative will have an important impact on more efficient learning. Finally, it will make one of the best ways to teach speaking, which can provide a good atmosphere for students to learn better and it will introduce a novel way of learning speaking through content-based instruction.

\section{Literature Review}

Teaching in general and language teaching in particular have always been a matter of wider extensive 
discussions. All human beings have to learn all the times and so the necessity for better learning and teaching methods have been felt in time and the technological developments and accordingly the expectations are raised to meet the requirements of the people. In this period of change and expansions, similar innovations would be created in the teaching of modern languages.

As we approach the present day, the need for alterations and improvements is felt more and this was the first motive for the researcher to initiate an experiment, which will certainly be of great importance for the learners / teachers, and beneficiaries who are in a way dealing with this field. Gaining the ability to speak a second or foreign language well is a very complex task if we try to understand the nature of what appears to be involved. Content- Based Instruction (CBI) is one of the most effective and meaningful language teaching approaches in recent years. Teachers can provide their students with content- based activities, which will make any syllabus more effective by making it student-centered, relevant and motivational.

According to Heatan (1990, p. 21), teaching and learning in one hand and learners motive are so closely related that it is virtually impossible to work in either field without being constantly concerned with the other. Regarding the role of learners, prompted the researcher to conduct an experiment in settings in which student centered approach is put against teacher-centered methods and consequently the impact on EFL learners speaking ability was compared and measured. Brown \& Hudson $(1998$, p. 22) stated that:" Wash back is the effect of teaching approach on the language-teaching curriculum that is related to it. Wash back is also backwash and the teaching style in various places in the literature". The researcher hopes this attempt yield the scholars, learners, and researchers a better view on student centered and teacher centered methods of teaching and learning.

The researcher assumes that one of the major drawbacks to the commonly used speaking approach do not result well in developing it. In fact, most of the learners consider speaking as an important ability to have which is useful in different situation. The present study aims at implementing the content-based approach in a student-centered environment with Iranian intermediate EFL learners to help them to interact in a realistic task such as panel discussion for better improvement of the speaking skill.

Content-based courses are now common in many different settings and content is often used as the organizing principle in ESL/EFL courses of many different kinds. In this paper, we will examine the principles underlying Content-Based Instruction and how these are applied in language teaching programs and teaching materials.

College (Sagliano \& Greenfield, 1998, p. 121) has published reports on how CBI courses are integrated into the curriculum at their respective institutions. In addition, the College and University Educators special interest group of JALT (Japan Association of Language Teachers) sponsored a conference at Keisen University in Tama, Tokyo, entitled "Content in Language Education: Looking at Future." The proceedings of this conference (Mackenzie, 2000, p. 52) reveal that a number of educators throughout Japan are involved in some form of CBI at their institutions.

CBI has primarily been used to teach students who already demonstrate relatively advanced skills in English. However, given the fact that the difficulty of the content can be adjusted, there is a strong possibility that CBI can be used successfully with low-level students. Yamane and Ryan (2000) address this issue in their description of courses for lower-level students taught at Sapientia University in Hyogo, Japan, in their article, Yamane and Ryan outline the challenge of teaching such content areas as sociolinguistics to lower-level students enrolled in an English linguistics/ communication course.

The present research will seek to convince an answer to the following question.

- Is there any relationship between content-based approach in students-centered environment and EFL learners' speaking ability?

\section{Methodology}

\subsection{Subjects}

The subjects who participated in this study consist of two groups of 30 male intermediate students who had participated in speaking course that was held in Kish-Air language institution. The range of the subjects was 16 to 23. Their major was not the same and they had different jobs and social positions. Some were high school students and some were university students of Payam Noor, Tehran Branch. Moreover, some were other people with different jobs.

They had passed the basic, elementary course with one-year long period and they were supposed to enter the intermediate course. All of these students were the same as far as they had passed the identical course. The two 
groups of the above subjects consisted of 60 students who were simply assigned to two classes through the process of registration of students in the center. One class served as the experimental group. The same teacher taught the two classes. It shall be noted that although the students of control and experimental were passing an identical speaking course, they were taught the strategies for better speech fluency. Both classes were held 2 days a week in the afternoon for 9 weeks.

\subsection{Instruments}

Two instruments are used to conduct the above-mentioned design: one was a pretest in order to ensure the homogeneity of the subjects in terms of linguistic knowledge; and an oral test in order to check the speaking ability of the subjects. Three proficient teachers helped the researcher to hold the oral tests. Therefore, when a learner was taking the test, he was observed and scored by four teachers. Then the average of the obtained scores accounted as one score of the testee. Partly in this procedure, it is said that our test has enough reliability.

The above-mentioned devices are pretests to have enough data for the statistical analysis of the study, a post test is also needed which is quite similar to the first tests. Though, we can use a pretest as post-test, if there are more than two weeks between them.

\subsection{Data Collection Procedures}

The subjects who participated in this study consist of two groups of 30 male Advance students who had participated in speaking course that was held in Kish language institution. The range of the subjects was 16 to 23 . At the very beginning of the course, the standardized examination and the teacher made final tests were administered to both experimental and control groups for determining their English language proficiency and their background knowledge of the course. The tests were administered to all the subjects during the same testing session to keep the administration conditions the same for the experimental and control group students. The two classes were taught through the same method, material, and instructor. The only difference between the experimental and control groups was the administration of five or six quizzes during the course.

The next step was to conduct the experimental treatment. The treatment of this study was in the form of repeated (intensive) measurement by handling quizzes during the course. The control group on the other hand, was not given any type of tests or quizzes during the course. Finally, at the end of the course in order to investigate the impact of the experimental treatment and to determine the relationship between and to determine variable (i.e., intensive quizzes' speech development), the teacher made final test was administered to both groups. The scores obtained from the experimental and control groups' performance.

\subsection{Data Analysis Procedure}

After collecting the data, the total pretest scores of the experimental group were compared to the total posttest scores of the same group through Match t-test. Then, the pretest scores of task were compared to the posttest scores of the same task in the experimental group in order to probe the research question. Afterwards, the total pretest and posttest scores of the experimental group were calculated statistically to be compared with the total pretest and posttest scores of the control group through Independent t-test in order to probe the first research question.

To have a more detailed comparison, we compared separately each single item specified in the evaluation form in the pretest task with the posttest task in the experimental group.

\section{Results}

Table 1. The comparison between the averages of the two groups' pre-test marks

\begin{tabular}{|c|c|c|c|c|c|c|c|c|c|c|}
\hline \multirow{3}{*}{ SCORE } & \multirow{3}{*}{$\begin{array}{l}\text { GROUP } \\
\text { experimental } \\
\text { Control }\end{array}$} & \multicolumn{2}{|l|}{$\mathrm{N}$} & \multicolumn{2}{|l|}{ Mean } & \multicolumn{2}{|c|}{ Std. Deviation } & \multicolumn{3}{|c|}{ Std. Error Mean } \\
\hline & & \multirow{2}{*}{\multicolumn{2}{|c|}{$\begin{array}{l}30 \\
30\end{array}$}} & \multicolumn{2}{|c|}{12.6167} & \multicolumn{2}{|c|}{1.69015} & \multicolumn{3}{|c|}{.30858} \\
\hline & & & & \multicolumn{2}{|c|}{12.6333} & \multicolumn{2}{|c|}{1.64492} & \multicolumn{3}{|l|}{.30032} \\
\hline & & \multicolumn{2}{|c|}{$\begin{array}{l}\text { Levene's Test for } \\
\text { Equality of } \\
\text { Variances }\end{array}$} & \multicolumn{7}{|c|}{ t-test for Equality of Means } \\
\hline & & \multirow[t]{2}{*}{$\mathrm{F}$} & \multirow[t]{2}{*}{ Sig. } & \multirow[t]{2}{*}{$\mathrm{t}$} & \multirow[t]{2}{*}{ df } & \multirow[t]{2}{*}{$\begin{array}{l}\text { Sig. } \\
\text { (2-tailed) }\end{array}$} & \multirow[t]{2}{*}{$\begin{array}{l}\text { Mean } \\
\text { Difference }\end{array}$} & \multirow[t]{2}{*}{$\begin{array}{l}\text { Std. Error } \\
\text { Difference }\end{array}$} & \multicolumn{2}{|c|}{$\begin{array}{l}95 \% \text { Confidence Interval } \\
\text { of the Difference }\end{array}$} \\
\hline & & & & & & & & & Lower & Upper \\
\hline \multirow[t]{2}{*}{ SCORE } & $\begin{array}{l}\text { Equal variances } \\
\text { assumed }\end{array}$ & .143 & .707 & -.039 & 58 & .969 & -.0167 & .43059 & -.87860 & .84526 \\
\hline & $\begin{array}{l}\text { Equal variances } \\
\text { not assumed }\end{array}$ & & & -.039 & 57.957 & .969 & -.0167 & .43059 & -.87861 & .84528 \\
\hline
\end{tabular}


Leven's test confirms the equality of variance. Therefore we use the first part of T-test for comparing the group marks. (T-test with equal variance) $(\mathrm{P}=0.707)$. The least meaningful level of independent $\mathrm{T}$-test represents that the average marks between two groups do not have an obvious difference. Surely, the average marks between two groups before the treatment do not have an obvious difference. $(\mathrm{P}=0.969)$.

Table 2. The comparison between the average of two groups' post-test marks

\begin{tabular}{|c|c|c|c|c|c|c|c|c|c|c|}
\hline & GROUP & \multicolumn{2}{|l|}{$\mathrm{N}$} & \multicolumn{2}{|l|}{ Mean } & \multicolumn{2}{|c|}{ Std. Deviation } & \multicolumn{3}{|c|}{ Std. Error Mean } \\
\hline \multirow[t]{5}{*}{ SCORE } & experimental & \multicolumn{2}{|l|}{30} & \multicolumn{2}{|c|}{16.3833} & \multicolumn{2}{|c|}{1.44844} & \multicolumn{3}{|l|}{.26445} \\
\hline & Control & \multicolumn{2}{|c|}{30} & \multicolumn{2}{|c|}{13.8333} & \multicolumn{2}{|c|}{1.74363} & \multicolumn{3}{|l|}{.31834} \\
\hline & & \multicolumn{2}{|c|}{$\begin{array}{l}\text { Levene's Test for } \\
\text { Equality of } \\
\text { Variances }\end{array}$} & \multicolumn{7}{|c|}{ t-test for Equality of Means } \\
\hline & & $\mathrm{F}$ & Sig. & $\mathrm{t}$ & $\mathrm{df}$ & $\begin{array}{l}\text { Sig. } \\
\text { (2-tailed) }\end{array}$ & $\begin{array}{l}\text { Mean } \\
\text { Difference }\end{array}$ & $\begin{array}{l}\text { Std. Error } \\
\text { Difference }\end{array}$ & $\begin{array}{l}95 \% \mathrm{Co} \\
\text { of the } \mathrm{D}\end{array}$ & ice Interval \\
\hline & & & & & & & & & Lower & Upper \\
\hline \multirow[t]{2}{*}{ SCORE } & $\begin{array}{l}\text { Equal variances } \\
\text { assumed }\end{array}$ & 1.205 & .277 & 6.162 & 58 & .000 & 2.5500 & .41385 & 1.72158 & 3.37842 \\
\hline & $\begin{array}{l}\text { Equal variances } \\
\text { not assumed }\end{array}$ & & & 6.162 & 56.113 & .000 & 2.5500 & .41385 & 1.72099 & 3.37901 \\
\hline
\end{tabular}

Leven's test confirms the equality of variances. ( $\mathrm{P}=0.277)$. According to the average marks of two groups we can say the experimental group marks are higher. $(\mathrm{P}=0.000)$

Table 3. The comparison between the average marks before and after the training

\begin{tabular}{llllll}
\hline & & Mean & $\mathrm{N}$ & Std. Deviation & Std. Error Mean \\
\hline Pair 1 & post test & 16.3833 & 30 & 1.44844 & .26445 \\
& pre test & 12.6167 & 30 & 1.69015 & .30858 \\
\hline
\end{tabular}

Table 4. Pearson's correlation test

\begin{tabular}{|c|c|c|c|c|}
\hline & & $\mathrm{N}$ & Correlation & Sig. \\
\hline Pair 1 & posttest \& pretest & 30 & .407 & .026 \\
\hline
\end{tabular}

Pearson's correlation test represents the relationship between the pre-test and post-test of experimental group marks is not meaningful $(\mathrm{P}=0.026)$.

Table 5. Dependent t-test

\begin{tabular}{|c|c|c|c|c|c|c|c|c|}
\hline & \multicolumn{8}{|c|}{ Paired Differences } \\
\hline & \multirow[b]{2}{*}{ Mean } & \multirow[b]{2}{*}{ Std. Deviation } & \multirow[b]{2}{*}{ Std. Error Mean } & \multicolumn{5}{|c|}{$95 \%$ Confidence Interval of the Difference } \\
\hline & & & & Lower & Upper & $\mathrm{t}$ & $\mathrm{df}$ & Sig. (2-tailed) \\
\hline posttest - pretest & 3.7667 & 1.72073 & .31416 & 3.1241 & 4.4092 & 11.990 & 29 & .000 \\
\hline
\end{tabular}

The last meaningful level of dependent T-test represents that the difference between the average marks of experimental group pre-test and post-test is meaningful. According to the average marks of experimental group pre-test and post-test we can say that the marks of experimental group post-test are improved. $(\mathrm{P}=0.000)$. 


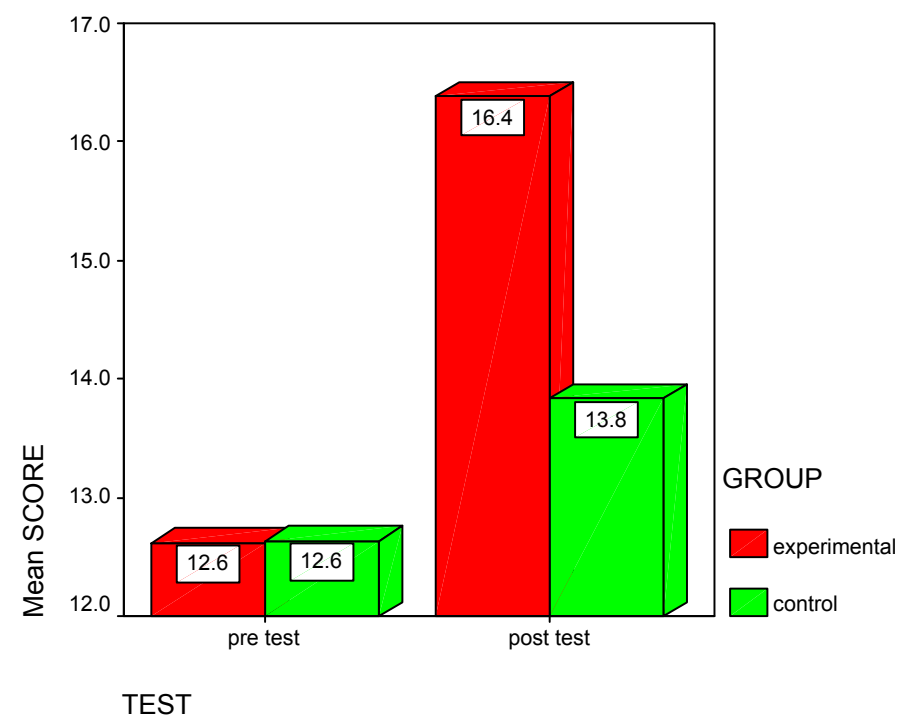

Figure 1. Comparison between pre-test scores and post-scores of control group and experimental group

\section{Discussion}

The major objective of the present study was to compare the effects of content-based approach vs. Teacher-centered environment on the improvement of speaking performance of Iranian advanced students. In this research, the independent variable in question hypothesis (content-based approach) which may influence the improvement of speaking performance on Iranian advanced EFL learners was examined. In order to determine whether content-based approach impacted significantly on speaking performance, the participants were divided into two groups; control and experimental. Hence, the two groups of learners were compared in terms of speaking performance before and after receiving treatment.

As it has been argued in the previous parts of this chapter, the EFL learners' speaking skills were significantly different between control and experimental groups. According to Independent t-test, the speaking performance among learners in the experimental group was more improved rather than the control group. So, this result shows the theoretical and statistical significant on the data. Based on the results, it was found that it has a meaningful effect on the speaking performance.

In order to find this matter, as we give treatment just to an experimental group, analyzed it and determined that if treatment create any difference between control group and experimental group or not. After performing the estimation, assessing the null hypothesis, with respect to the value of test probability i.e. sig which is $<0.05$ we found that the null hypothesis will be rejected.

Status of scores distribution will be determined with the scores of students with Skewness and kurtosis test of normality. The homogeneity of variances was determined by Levene test. After homogenizing independent samples test was used for analyzing the difference between control and experimental groups. With respect to the tests of normality we found that these two groups don't have a meaningful difference in pretest but in posttest according to test of normality of Skewness and kurtosis test we found that there is a meaningful difference between control and experimental group in post with performing the treatment.

Also for calculating the reliability of multi-option tests, we used Cronbach's alpha. In this method, if the value of alpha is more than 0.7 questionnaires have the required reliability and as we can see, the value of alpha is 0.719 that verify the reliability of the test. At the end, it is verified that content-based approach has statistically significant positive effects on improving the speaking performance on Iranian advanced EFL students.

\section{Conclusion}

Almost all the researchers in the field of TEFL believe that student centered classes in content-based approach show good outcomes in practice, although much of these researchers believe in this method of teaching model in the English classes. During this study, in spite of the entire problem, the researcher managed to investigate two classes. One as experimental and the other as control one. The two classes were held in the afternoon. They were both taught by the same teacher. Subjects were all homogenous regarding their age, gender and first language. 
During the experiment, the experimental group was given quizzes every once in a while during the first quarter of class time and the control group was not given any tests during the course.

The feedback through the orals and quizzes administered was received from the experimental group. The report of the scales was given to the students after each quiz. At the end, a final test was administered to both groups. To attain the impact required, the researcher compared two groups' performances at the end. So the scores of two groups were compared on the final test. Thus, null hypothesis was rejected and the results indicate that a statistically significant positive relationship exists between giving the students the central role in content-based approach class and yielding in better performance of speaking ability of EFL learners.

\section{References}

Allwright, D. (1988). Observation in the language classroom. London: Longman London Group Ltd. Press.

Bachman, F. (1995). Fundamental considerations in language testing. Boston: Boston Heinle Publishers.

Brown, J. D. (1988). Understanding research in second language learning: a teacher's guide to statistics and research design. Cambridge: Cambridge University Press.

Chastain, K. (1988). Developing second language skills theory and practice. California: Harcourt Bruce Jovanovich, Inc.

Cook, V. (1994). Second language learning and teaching. Boston: Boston Heinle Publishers.

Douglas, B. H. (2004). Teaching by principles. London: Longman Pearson Publication.

Elizabeth, B., \& Ellen, R. E. (1999). Learning how to learn English from awareness to action. Cambridge: Cambridge University Press.

Ellies, R. (2003). Task-based language learning and teaching. Oxford: Oxford University Press.

Ellis, R. (1990). Instructed second language acquisition. Oxford: Oxford University Press.

Harmer, J. (1998). How to teach English. London: Longman Pearson Publication.

Hedge, T. (2000). Teaching and learning in the language classroom. Oxford: Oxford University Press.

Herbert, W., \& Shohamy, E. (1999). Second language research methods. Oxford: Oxford University Press.

Horwitz, E. (1987). Surveying student beliefs about language learning, learner strategies in language learning. New York: Prentice Hall International.

Huges, A. (1989). Testing for language teachers. Cambridge: Cambridge University Press.

Molly, J. (2002). Learner centered education as a model and platform for training graduate teaching assistants in professional skills. Arizona: Arizona University Press.

Murphy, D. (1986). Communication and correction in the classroom. ELT Journal, 40(2), 141-152. http://dx.doi.org/10.1093/elt/40.2.146

Nuna, D. (1999). Second language teaching and learning. Massachusetts: Heinle Publishers.

Richards, J. (2003). Methodology in language teaching. Cambridge: Cambridge University Press.

\section{Copyrights}

Copyright for this article is retained by the author(s), with first publication rights granted to the journal.

This is an open-access article distributed under the terms and conditions of the Creative Commons Attribution license (http://creativecommons.org/licenses/by/4.0/). 